\title{
Trout Use of Woody Debris and Habitat in Appalachian Wilderness Streams of North Carolina
}

\author{
Patricia A. Flebbe and C. Andrew Dolloff \\ Southern Research Station, U.S. Forest Service and \\ Department of Fisheries and Wildlife Sciences, Virginia Polytechnic Institute and State University \\ Blacksburg, Virginia 24061-0321, USA
}

\begin{abstract}
Wilderness areas in the Appalachian Mountains of North Carolina are set aside to preserve characteristics of both old-growth and second-growth forests and associated streams. Woody debris loadings, trout habitat, and trout were inventoried in three southern Appalachian wilderness streams in North Carolina by the basin-wide visual estimation tcchniquc. Two streams in old-growth wilderness areas contained more large woody debris (LWD, diameter $>10 \mathrm{~cm}$ ) and more and smaller pools and riffles than did a stream in a second-growth area managed as wilderness. Furthermore, the size distribution of woody debris in the second-growth stream was skewed to smaller size-classes than that in the old-growth streams. Brook trout Salvelinus fontinalis, rainbow trout Oncorhynchus mykiss, and brown trout Salmo trutta in the three streams were always found in habitat units that had large amounts of LWD but were present in only $70-90 \%$ of the large number of units with little or no LWD. In the absence of high fishing pressure, the stream with large amounts of LWD supported higher trout density and biomass than the stream with little or no LWD. These old-growth streams provide a benchmark against which recovery of previously disturbed streams may be compared. Furthermore, if the goal for restoration of trout habitat is to recreate old-growth stream conditions, these two old-growth wilderness streams provide a basis for selecting appropriate amounts and sizes of LWD.
\end{abstract}

In the southern Appalachian Mountains of North Carolina, only small amounts of true old-growth forest (i.e., forest never harvested for timber or cleared for homesteads) escaped a major expansion of the logging industry that began after 1880 (Williams 1989). Because of its rarity and historical value, most of the remaining old growth is currently managed as wilderness where timber harvesting and other mechanized activities are prohibited. Such preservation maintains structural and functional characteristics of old growth that are not found in second-growth forests of the region. Old-growth forests are characterized by multiple vegetation layers, an abundance of coarse woody debris on the forest floor, and structurally complex habitat for wildlife (Franklin et al. 1981; Franklin 1992). Streams that flow through old-growth forests also exhibit distinct characteristics such as higher levels of nutrients (Vitousek and Reiners 1975; Silsbee and Larson 1983) and more abundant large woody debris (LWD) (Franklin et al. 1981; Silsbee and Larson 1983; Harmon et al. 19X6; Bisson et al. 1987) than streams in secondgrowth forests. In streams, LWD maintains physical stability by creating stepped profiles that dissipate energy and retain sediments and provides a range of habitats for stream organisms (Franklin et al. 1981; Harmon et al. 19X6; Bisson et al. 19X7; Grant et al. 1990; Naiman et al. 1992). Large woody debris also provides cover for fish (Dolloft 1986) and substrate for macroinvertebrates (Harmon et al. 1986).

Wilderness has also been established in areas of North Carolina that were logged in the last century. In the southern Appalachians, many of these areas are relatively mature forested watersheds, but they still lack some characteristics of old-growth forests. Ecological characteristics of streams flowing through the second-growth forest in these previously logged or settled wilderness areas may differ from streams that drain old-growth wilderness forest. In particular, many relatively mature secondgrowth watersheds were logged at times when the stream was cleared of woody material to facilitate transport of titnber (Dolloff 1994). In these watersheds, trees are not yet as large as those in oldgrowth forests, and because the amount and size of woody material that each forest contributes to stream habitats is directly linked to the vegetative composition of the riparian zone, these streams may lack the woody structure of streams in oldgrowth watersheds (Bryant 1980; Silsbee and Larson 1983; Bisson et al. 1987; Andrus et al. 1988; Hicks et al. 1991; Murphy and Meehan I99 1; Flebbe and Dolloff 1993). Consequently, these streams may also lack habitat structure for fish.

Although wilderness areas may be set aside to serve particular values, these areas arc important 


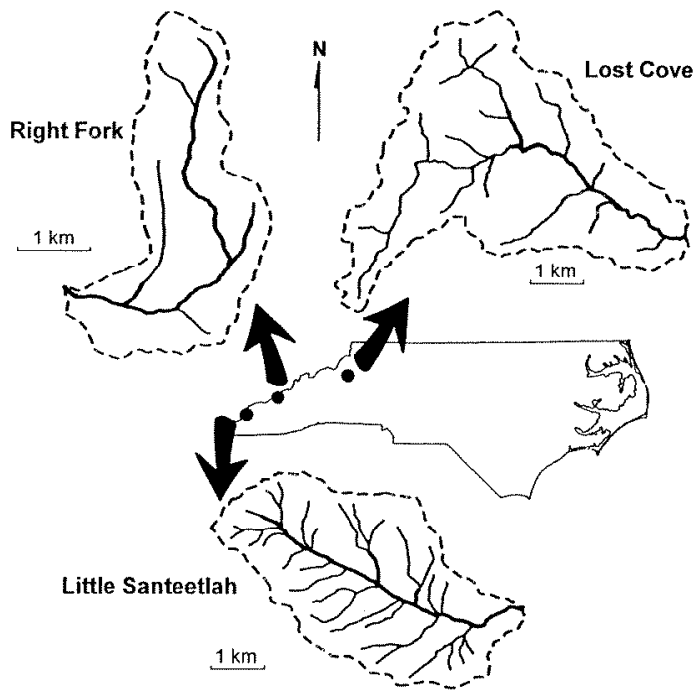

Figure 1 --Location of wilderness stream study areas in North Carolina and basin maps. Dashed lines arc watcrshcd boundaries, and solid lines are streams. Heavier solid lines denote portions of the streams surveyed for this study. Right Fork basin map is at a larger scale than Little Santeetlah and Lost Cove basin maps.

for multiple uses. In the southern Appalachians, fishing for trout is an important recreational activity, and some anglers prefer to fish wilderness streams. Relatively limited vehicular access may discourage other, less determined anglers from fishing these streams. Three species of trout, native brook trout Salvelinus fontinalis and introduced rainbow trout Oncorhynchus mykiss and brown trout Salmo trutta are found in mountain streams of North Carolina.

These two kinds of " wilderness provide different amounts of LWD (Silsbee and Larson 1983; Flebbe and Dolloff 1993) and habitat (pools and riffles) (Flebbe and Dolloff 1993), but how do trout use the habitat associated with LWD in wilderness streams? This paper describes and compares sal- monid use of habitat with and without woody debris in three North Carolina headwater streams that drain forested wilderness areas. Two streams were located in true old-growth forest, whereas land surrounding the third stream was logged about 80 years ago. Major objectives were to compare the amount and size distribution of woody debris in stream channels; to compare the number, frequency, and type of habitat units; and to determine salmonids' use of habitat units with different amounts of LWD in these three wilderness streams.

\section{Study Sites}

Three headwater trout streams of approximately the same size (width and length) in the coldwater area of North Carolina's Appalachian Mountains (Blue Ridge Province) were selected for study (Figure 1; Table 1). All three streams drain south and east slopes of mountain ridges, which generally trend southwest to northeast. Watersheds are presently managed by the U.S. National Park Service and U.S. Forest Service as wilderness but have different management histories. Two streams, Right Fork and Little Santeetlah Creek, are in oldgrowth forested watersheds, and the third, Lost Cove Creek, is in a second-growth forested watershed. Channel types (Rosgen 1YY4) are similar in all three streams, a mixture of types A and B. The three stream systems are also found at different elevations and have different salmonid faunas. Native brook trout are commonly found at highest elevations, with introduced rainbow trout at lower elevations in the same streams (Larson and Moore 1985). Introduced brown trout are much less common and are also found at lower elevations than brook trout and rainbow trout (Flebhe 1994). The three streams were selected to represent a range of wilderness conditions from a very remote brook trout stream at highest elevation, Right Fork, to a rainbow trout stream at lowe

TABLEI - Site descriptions of three study streams in the Appalachian Mountains of North Carolina

\begin{tabular}{|c|c|c|c|}
\hline Description & Right Fork & Little Santeetlah & Lost Cove \\
\hline Known disturbance history & None & None & $\begin{array}{l}\text { Logged 1910s; tire 1910s; } \\
\text { floods 1916, 1940 }\end{array}$ \\
\hline Siream orders surveyed & $1-2$ & $1-3$ & $2-3$ \\
\hline Watershed area $\left(\mathrm{km}^{2}\right)$ & 7.2 & 15.3 & 20.5 \\
\hline Survey elevation (m) & $1,280-1,580$ & $620-1,210$ & $550-800$ \\
\hline Length surveyed $(\mathrm{km})$ & 7.1 & 6.1 & 6.4 \\
\hline Gradient $(\%)$ & 5.0 & 9.9 & 4.0 \\
\hline Width $(m)^{i i}$ & 3.6 & 4.5 & 4.7 \\
\hline Trout species & Brook, ranbow & Rainbow, brook & Brown, rainbow, brook \\
\hline
\end{tabular}

average widths measured at midsummer low flow. 
elevation, Little Santeetlah Creek, and a brown trout stream, Lost Cove Creek.

Right Fork of Raven's Fork (Figure I; Table 1) is a second-order stream at the highest elevations of' the Oconoluftee drainage in the Great Smoky Mountains National Park (Swain County, North Carolina). There is no evidence that this basin was ever disturbed by fire, logging, or agriculture, and its upper forest is considered a virgin mixture of spruce Picea rubens and fir Abies fraseri (Pyle 1985). Spruce and fir are found only on the upper slopes of the basin, and mixed hardwoods are found on lower slopes and in the riparian areas. Eastern hemlock Tsuga canadensis is a major component of the riparian area. Brook trout predominate in this stream, and a few rainbow trout are found in lower portions of the stream. No other fish species are known to be present. Fishing pressure is low because access to the stream is by foot travel only, and the nearest road is at least $5 \mathrm{~km}$ away. We inventoried 7. I km of first- and secondorder stream occupied by trout above the confluence of the Left, Middle, and Right Forks of Raven's Fork.

Little Santeetlah Creek (Figure I; Table 1) is a third-order stream that drains the Joyce Kilmer Memorial Forest in the Nantahala National Forest of western North Carolina (Graham County). This tract was set aside in 1936 as a memorial to the poet Joyce Kilmcr and was never logged. Since 1975 the Memorial Forest has been included in the Joyce Kilmer-Slickrock Wilderness Area. The upper watershed, one of' the few virgin forest tracts remaining in the southern Appalachians, is dominated by tuliptree Liriodendron tulipifera, eastern hemlock, basswood Tilia spp., silverbell Halesia carolina, beech Fagus grandifolia, maples Acer spp., and oaks Quercus spp. (Lorimer 1980). Before the chestnut blight, American chestnut Castanea dentata was a major canopy dominant, and very large chestnut logs remain on the forest floor. A portion of the riparian forest has been aged at 334 years (Hedman 1992), and individual trees in the basin have been aged at about 400 years (Lorimer 1980). The base of the watershed is easily accessed by road; however, only foot travel is permitted within the watershed. Fishing pressure is probably moderate to high. Rainbow trout occupy most of' Little Santeetlah Creek, and brook trout become more common in the headwaters. We inventoried $6.1 \mathrm{~km}$ of stream beginning at the confluence with Big Santeetlah Creek and working upstream to where trout were no longer found. We included two tributaries, Indian Spring and Daviscamp Creek.

Lost Cove Creek (Figure 1; Table I) is a thirdorder stream in the Wilson Creek Area of the Pisgah National Forest (Avery County, North Carolina). We inventoried $6.4 \mathrm{~km}$ of the stream above a minor tributary at $550 \mathrm{~m}$ elevation. Like many areas in the Appalachian Mountains, Lost Cove Creek was logged about 80 years ago when entire drainages, including streamsides, were clear-cut. Presently the watershed is vegetated by mixed hardwoods: oaks, hickories Carya spp., maples, yellow birch Betula alleghaniensis, and sycamore Platanus occidentalis. Major floods occurred in the drainage in 1916 and 1940. Although not formally set aside under provisions of the 1974 Wilderness Act, Lost Cove Creek is being considered for wilderness status and is managed as if' it were wilderness. Vehicular access (4-wheel drive only) into this watershed, which facilitated moderate fishing pressure during our study, has since been closed. Rainbow trout and brown trout are found throughout the inventoried section of Lost Cove Creek; brook trout occur only in the uppermost habitat units. Overall gradient is $3-4 \%$, although a tributary, Sassafras Creek $(0.9 \mathrm{~km})$, has a gradient of $13 \%$.

Riparian vegetation in all three stream systems was similar even though the upland forests differed. Overstory vegetation in Little Santeetlah is dominated by hemlock, with birch, yellowwood Cladrastis lutea, beech, mountain-laurel Kalmia latifolia, tuliptree, and Fraser magnolia Magnolia fraseri also in the overstory (Hedman 1992). Riparian vegetation was similar in Right Fork, but Lost Cove Creek had less hemlock (authors' personal observation). Rhododendron (Rhododendron spp.) is the most common understory component of all three riparian areas (Hedman 1992; authors' personal observation).

\section{Methods}

Streams were inventoried during summer 1988, a period of " low flow, with visual estimation techniques and the basin survey method of Hankin and Reeves (1988). Habitat units were identified and assigned to one of' four habitat types (modified from Platts et al. 1983): pools (unbroken surface, slow velocity, deep water), glides (rippled surface, faster velocity, shallow water, often uniform small substrate), riffles (streambed substrate protruding through water surface, gradient $<12 \%$ ), and cascades (large boulder or bedrock substrate, gradient $\geq 12 \%$ ). Length along thalweg for each unit was 
TABle 2.- Size-classes of woody debris in streams (after Dolloff et al. 1993).

\begin{tabular}{ccccc}
\hline & \multicolumn{3}{c}{ Diameter } & \\
\cline { 2 - 4 } Length & $5-10 \mathrm{~cm}$ & $>10-50 \mathrm{~cm}$ & $>50 \mathrm{~cm}$ & Rootwads \\
\hline $\mathrm{I}-\mathrm{S} \mathrm{m}$ & Class I & Class 2 & Class 3 & Class 7 \\
$>5 \mathrm{~m}$ & Class 4 & Class 5 & Class 6 & Claw 7 \\
\hline
\end{tabular}

measured with a hip chain, and the area $\left(\mathrm{m}^{2}\right)$ of each pool and glide and width (m) of each riffle and cascade were visually estimated. We calibrated visual estimates by measuring widths of $10 \%$ of the riffles and about $7 \%$ of the cascades and areas of $20 \%$ of the pools and glides with a tape measure (Dolloff et al. 1993).

Woody debris greater than $5 \mathrm{~cm}$ in diameter and $1 \mathrm{~m}$ long in each habitat unit was counted and assigned to one of seven size-classes (Table 2). All pieces of woody debris that had some portion within the bank-full channel were counted, including pieces that spanned or leaned across the channel and that would be wetted during bank-full flows. Large woody debris is defined as woody debris 10 $\mathrm{cm}$ or more in diameter (classes 2-3 and S-7 in Table 2) (Meehan 1991); these size-classes often contribute structure to the habitat unit in which they are found. Woody debris of small diameter is relatively mobile and does not add significantly to the structure of habitats unless associated with larger woody pieces, for example, incorporated into a debris dam (Bilby and Likens 1980). Boulder substrate tnay function as a surrogate for LWD in these streams; therefore, dominant and codominant substrate for each unit was assigned by class: bedrock. boulder $(>30 \mathrm{~cm})$, cobble $(11-30 \mathrm{~cm})$, large gravel $(1-10 \mathrm{~cm})$, small gravel $(2-10 \mathrm{~mm})$, or sand $(<2 \mathrm{~mm}$, including also silt, clay, or organic debris).

We calibrated habitat area estimates according to equations developed by Hankin and Reeves (1988), using SAS programs (SAS Institute 1985) developed by the first author. Because numbers of glides and cascades were inadequate to calibrate estimates, we combined glides and cascades with pools and riffles, respectively, for analysis and in the following discussion. Counts of woody debris and habitat units were standardized to total stream length surveyed to allow comparisons among streams.

In each measured habitat unit, snorkelers visually estimated numbers of trout (Dolloff et al. 1993). Snorkelers assessed 142 units in each of Right Fork and Little Santeetlah Creek and 100 units in Lost Cove Creek, all during middle daylight hours under good visual conditions. At least $10 \%$ of the habitat units assessed by snorkelers (29, 22, and 26 units, respectively, in Right Fork, Little Santeetlah Creek, and Lost Cove Creek) were sampled by multiple-pass depletion electrofishing (to approximately 80\% depletion) (Zippin 1958 ) to verify counts of trout (Hankin and Reeves 1988; Dolloff et al. 1993). Conductivity and visual clarity during electrofishing were similar in all three streams. Individual fish were weighed to the nearest $0.1 \mathrm{~g}$ with an electronic balance. At completion, all individuals were returned alive to the approximate location of capture. Units for snorkeling and electrofishing were distributed systematically (every 5 th, 10 th, or 15 th unit) throughout the basin after random selection of the first (downstream) unit.

We compared amounts of woody debris and habitat among the three streams and among reaches selected to match width and gradient as closely as possible (Table 3). We selected the lowest $2.0 \mathrm{~km}$ on Right Fork, up to a small tributary at $1,370 \mathrm{~m}$ elevation: a middle $2.5 \mathrm{~km}$ section on Little Santeetlah Creek, between tributaries at $670 \mathrm{~m}$ and

TABLE 3.-Average width, overall gradient, counts of large woody debris (LWD) $10 \mathrm{~cm}$ or greater in diameter, counts of trout habitat units, and mean (SD) areas of habitat units in selected reaches. Total counts of LWD and habitat units are standardized to number per kilometer to allow comparisons. Total counts of L.WD were signilicantly different among streams (chi-square against even distribution; $P<0.00$ 1) hut numbers of pools and riffles were not signilicantly different (chi-square; $P>0.05$ ). Pool and riffle areas were signilicantly different amongstreams (ANOVA; $P=0.001$ ); different lowercase letters denote streams that were significantly different (least significant difference; $P<0.05$ ).

\begin{tabular}{|c|c|c|c|c|c|c|c|}
\hline \multirow[b]{2}{*}{ Stream (reach) } & \multirow[b]{2}{*}{$\begin{array}{l}\text { A verage } \\
\text { width } \\
\text { (m) }\end{array}$} & \multirow[b]{2}{*}{$\begin{array}{c}\text { Gradient } \\
(\%)\end{array}$} & \multirow{2}{*}{$\begin{array}{c}\text { Total } \\
\text { LWD } \\
\text { (num- } \\
\text { ber/km) }\end{array}$} & \multicolumn{2}{|c|}{ Total units } & \multirow[b]{2}{*}{$\begin{array}{l}\text { Mean pool } \\
\text { area }\left(\mathrm{m}^{2}\right)\end{array}$} & \multirow[b]{2}{*}{$\begin{array}{c}\text { Mean riffe } \\
\text { afea }\left(\mathrm{m}^{2}\right)\end{array}$} \\
\hline & & & & $\begin{array}{c}\text { Pools } \\
\text { (num- } \\
\text { ber } / \mathrm{km} \text { ) }\end{array}$ & $\begin{array}{l}\text { Riffles } \\
\text { (ntm- } \\
\text { ber/km) }\end{array}$ & & \\
\hline Right Fork (lower 2.0 km) & 4.2 & 4.6 & 206 & 77 & 56 & $29.6(25.2) \mathrm{y}$ & $41.6(50.7)$ I \\
\hline Litte Santeetah (middle $2.5 \mathrm{~km}$ ) & 4.6 & 5.8 & 111 & 95 & 69 & $20.4(15.7) 7$ & 40. I (44.2) 7. \\
\hline Lost Cove (upper 2. I km) & 4.x & 4.7 & 14 & 65 & 46 & $37.9(35.9) \times$ & $6 \times .7(91.9) y$ \\
\hline
\end{tabular}




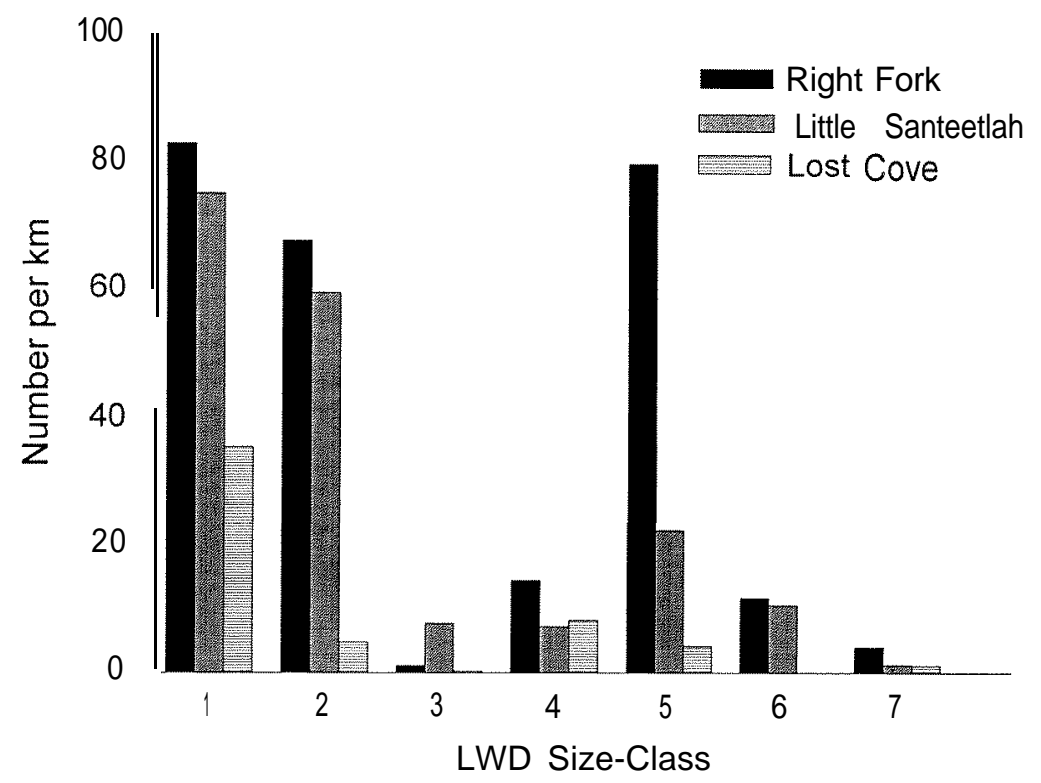

FIGURE 2.-Average number of pieces of large woody debris (LWD) per kilometer of stream in Right Fork and Little Santeetlah Creek (old growth) and Lost Cove Creek (logged). Size-classes 1-7, displayed from left to right, are defined in Table 2

$820 \mathrm{~m}$ elevation; and the uppermost $2.1 \mathrm{~km}$ on the mainstem of Lost Cove Creek, above a tributary at $610 \mathrm{~m}$ elevation. The reaches on Little Santeetlah and Lost Cove Creek were also at closely matched elevations; similar elevations are not found on Right Fork. Chi-square tests were used to compare woody debris and habitat count data in the three streams to the null hypothesis of equal counts (mean of actual counts); analysis of variance (ANOVA) and least-significant-difference tests were used to compare pool and riffle areas among streams.

To determine the relationship between trout and LWD, we matched the trout data with the corresponding habitat data for each unit assessed by snorkelers. The number of pieces of LWD was determined for each of these habitat units. If trout were not observed in a unit by snorkelers but were subsequently captured by electrofishing, trout were assumed to be present in the unit. Chi-square tests were used to compare trout use of units with different amounts of LWD $(0,1,2,3$, and $\geq 4$ pieces of LWD) among streams, species, and habitat types. Similar comparisons among selected reaches were not possible because sample sizes were too small. Trout density (number/m') and biomass $\left(\mathrm{g} / \mathrm{m}^{*}\right)$ were not normally distributed, so we compared them among streams and among units with different amounts of LWD with the
Kruskal-Wallis nonparametric test, followed by a nonparametric pairwise comparison procedure (Neter et al. 1990546). Back-transformed geometric mean $\left(\log _{e}[x+1]\right.$ transform) values are reported.

\section{R esults}

Right Fork had 1,836 and Little Santeetlah Creek 1,105 pieces of woody debris, compared to 342 pieces in Lost Cove Creek. When standardized to a per-kilometer basis, Right Fork and Little Santeetlah Creek had 4.9 and 3.4 times as much wood per kilometer as Lost Cove Creek $(260,182$, and $53 / \mathrm{km}$, respectively; chi-square significant, $P<$ 0.001). Distributions of woody debris among the seven size-classes were also different for the three stream systems (Figure 2). A chi-square test of these differences (Figure 2) was not possible because of sparse data $(>20 \%$ of cells in the $7 \times 3$ contingency table had frequencies of $<5$ ), but chisquare tests were significant $(P<0.001)$ for two reduced $(4 \times 3)$ contingency tables: class 7 deleted and classes 2 and 3 and classes 5 and 6 combined; and class 7 deleted and classes 2 and 5 and classes 3 and 6 combined. In nearly every case, more wood was found in each size-class in the two old-growth streams than in Lost Cove Creek (Figure 2). About $81 \%$ of the wood tallied in Lost Cove Creek was in classes I and 4 (Figure 2), which represents 
TABLE 4.-Counts of large woody debris (LWD) $10 \mathrm{~cm}$ or greater in diameter, counts of trout habitat units, and mean (SD) areas of habitat units in study streams. Total counts of LWD and habitat units are standardized to number per kilometer to allow comparisons. Total counts of LWD and units with LWD were significantly different among streams (chi-square against even distribution; $P<0.001$ ) hut numbers of pools and riffles were not significantly different (chisquare; $P>0.05$ ). Pool and riffle areas were significantly different among streams (ANOVA; $P=0.0001$ ); different lowercase letters denote streams that were significantly different (least significant difference; $P<0.05$ ).

\begin{tabular}{|c|c|c|c|c|c|c|}
\hline \multirow[b]{2}{*}{ Stream } & \multirow[b]{2}{*}{$\begin{array}{l}\text { Total LWD } \\
\text { (number } / \mathrm{km})\end{array}$} & \multirow{2}{*}{$\begin{array}{l}\text { Units with } \\
\text { LWD } \\
\text { (number } / \mathrm{km} \text { ) }\end{array}$} & \multicolumn{2}{|c|}{ Total units } & \multirow[b]{2}{*}{$\begin{array}{l}\text { Mean pool area } \\
\left(\mathrm{m}^{2}\right)\end{array}$} & \multirow[b]{2}{*}{$\begin{array}{c}\text { Mean riffle area } \\
\left(\mathrm{m}^{2}\right)\end{array}$} \\
\hline & & & $\begin{array}{c}\text { Pools } \\
\text { (number } / \mathrm{km} \text { ) }\end{array}$ & $\begin{array}{c}\text { Riflles } \\
\text { (number } / \mathrm{km} \text { ) }\end{array}$ & & \\
\hline Right Fork & 162 & 61 & 73 & 60 & $21.3(20.0) \quad z$ & $37.4(44.9) \quad z$ \\
\hline Little Santeetlah & 100 & so & $x 3$ & 75 & $21.4(22.3) z$ & $37.3(47 . X) 7$ \\
\hline Lost Cove & 10 & $x$ & 62 & 44 & $55.2(88.1) y$ & $61.6(90.4) y$ \\
\hline
\end{tabular}

recruitment of small-diameter material such as branches and small trees from the second-growth riparian forest. In the two old-growth forest streams, these size-classes were even more abundant but contributed only $37 \%$ of the woody debris in Right Fork and $45 \%$ in Little Santeetlah Creek because larger wood was even more common in these streams (Figure 2). Much of this small material had accumulated with larger pieces in debris dams in the two old-growth forest streams; 61. I \% (Little Santeetlah) and $81.5 \%$ (Right Fork) of the smallest woody debris (class 1) was associated with LWD, compared to only $24.0 \%$ in Lost Cove Creek. Right Fork had a large amount of woody debris $10-50 \mathrm{~cm}$ in diameter and greater than $5 \mathrm{~m}$ long (class 5) (Figure 2). These pieces of wood were found both individually and associated with large debris dams. Debris dams were more important in Right Fork and Little Santeetlah Creek: 8.7 and $3.8 \%$ of habitat units had more than five pieces of woody debris, respectively, compared to only $1.4 \%$ of units in Lost Cove Creek.

Right Fork and Little Santeetlah Creek had 1016 times as much LWD as did Lost Cove Creek, and many more habitat units had LWD (Table 4). In Right Fork and Little Santeetlah Creek, 46 and $32 \%$ of habitat units had LWD, but in Lost Cove Creek, only $7 \%$ of units had LWD (Table 4). Thus, numbers of units with LWD were significantly different from total number of pools and riffles (Table 4; chi-square, $P<0.001)$. The two old-growth streams contained more pools and riffles per kilometer than did Lost Cove Creek, but differences were not significant (Table 4; chi-square, $P>$ 0.05). Furthermore, average size of pools and riffles was at least $50 \%$ greater in Lost Cove Creek than in Right Fork and Little Santeetlah Creek, and the differences were significant (Table 4; ANOVA, $P<0.05)$. Average depths of pools with LWD were slightly greater than those without
LWD, but the difference was significant only in Right Fork (t-test, $P<0.001$ ).

All three selected reaches had more LWD and pools and generally fewer riffles than their respective streams, but the differences were mostly small (Tables 3, 4). The amount of LWD and average size of pools in the selected reach of Right Fork, however, were somewhat greater than the stream as a whole, probably because of the relatively large number of debris dams in this section of stream (authors' personal observation). Differences among these stream reaches were similar to those just described for the whole streams (Table 3).

Trout generally selected the units that contained the most LWD, particularly in Little Santeetlah Creek (Figure 3). Many habitat units assessed by snorkelers in all three streams contained no LWD; in Lost Cove Creek, however, units with no LWD were much more common (91\% of habitat units) than in Right Fork $(50 \%)$ or Little Santeetlah $(61 \%)$ (Figure 3). Most of the units that lacked LWD were occupied by trout, but rates of occupancy generally increased with increasing amounts of LWD. Rates of occupancy in Right Fork units appear to be relatively uniform (Figure 3); however, all 10 units with five or more pieces of LWD were occupied by trout. Snorkeler-assessed habitat units contained no more than 4 pieces of LWD in Lost Cove Creek but contained up to 10 pieces in Right Fork and 7 in Little Santeetlah Creek. Units with large amounts of LWD (four pieces or more) were nearly always occupied in all three streams; only one unit with four pieces of LWD was unoccupied in Right Fork. A chi-square test of the 5 $X 3$ contingency table (i.e., $0,1,2,3$, or $\geq 4$ LWD pieces $\mathrm{X}$ three streams) of proportions of units occupied by trout was significant $(P<0.001)$, indicating that distributions of trout among units with different amounts of LWD were independent 


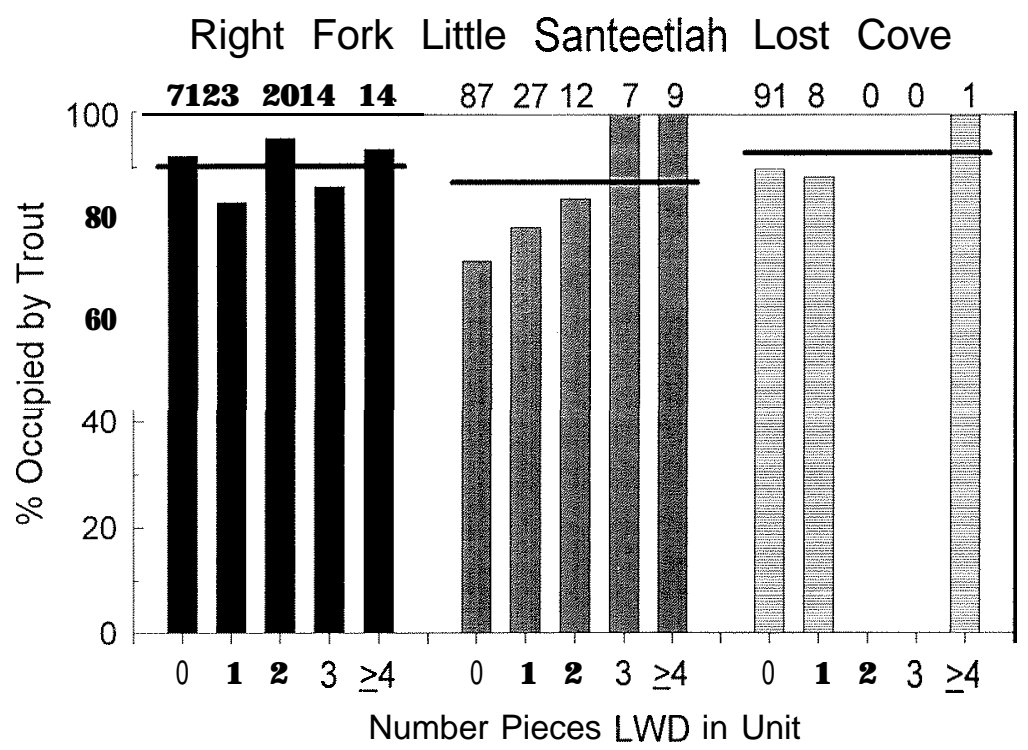

FlguRE 3. - Selection of habitat units with large woody debris (LWD) by trout in three study streams. Height of each bar represents the percentage of units with given amounts (number of pieces) of LWD (size-classes 2, 3, 5,6 , and 7 in Table 2) occupied by trout. Numbers above each bar give the total number of units with the given amounts of LWD. Horizontal lines across each set of bars represent the average rate of occupancy; bars higher than this line are overoccupied and bars lower are underoccupied compared to the average rate.

of stream. Similar chi-square comparisons among pairs of streams were significant $(P<0.0001)$ for Lost Cove Creek versus Right Fork and Little Santeetlah Creek but were not significant between Right Fork and Little Santeetlah Creek $(P>0.05)$. Thus, trout USC of units with different amounts of LWD was similar in the two streams in old-growth areas but differed in the stream surrounded by second growth.

Boulders were more common in Lost Cove Creek, where they were the dominant or codominant substrate in $67 \%$ of the habitat units. com-

TABLE S.-Number of stream units with different amounts $(0, I, 2,3$, or $\geq 4$ pieces) of large woody debris (LWD) occupied by each specks of trout. Column distributions arc not significantly different from corresponding distributions of aggregated trout species displayed in Fig. ure 3 (chi-square, $P>0.5$ ).

\begin{tabular}{|c|c|c|c|c|c|}
\hline \multirow[b]{2}{*}{$\begin{array}{l}\text { Pieces } \\
\text { of LWD }\end{array}$} & \multirow{2}{*}{$\begin{array}{l}\text { Right } \\
\text { Fork, } \\
\text { brook } \\
\text { trout }\end{array}$} & \multirow{2}{*}{\multicolumn{2}{|c|}{$\begin{array}{l}\text { Little } \\
\text { San- } \\
\text { teetlah } \\
\text { Creek, } \\
\text { tainbow } \\
\text { trout }\end{array}$}} & \multicolumn{2}{|c|}{ Lost Cove Creek } \\
\hline & & & & $\begin{array}{c}\text { Rainbow } \\
\text { trout }\end{array}$ & $\begin{array}{c}\text { Brown } \\
\text { trout }\end{array}$ \\
\hline None & 65 & \multirow{5}{*}{1} & 59 & 40) & 64 \\
\hline One & 19 & & 20 & 2 & 4 \\
\hline Two & 19 & & 10 & & \\
\hline Three & 12 & & 7 & & \\
\hline Four or more & 13 & & 9 & 1 & 1 \\
\hline
\end{tabular}

pared to $49 \%$ of units in Little Santeetlah Creek and $18 \%$ in Right Fork. Of 91 units in Lost Cove Creek that lacked LWD, 59 had boulder substrate, and $90 \%$ of these units were occupied, nearly equal to the $88 \%$ of units with neither LWD nor boulders. Similarly, in Right Fork, 15 units without LWD had boulder substrate, and all were occupied, compared to $89 \%$ of the 56 units that had neither LWD nor boulders. Finally, in Little Santeetlah Creek, only $60 \%$ of 40 units that had boulders and no LWD were occupied by trout, whereas $8 \mathrm{I} \%$ of the 47 units that lacked both LWD and boulders were occupied.

Ideally, these analyses would be conducted separately for each species and habitat type; however, sample sizes did not permit a complete analysis. Brown trout did not occur in Right Fork or Little Santeetlah Creek. Brook trout occurred in only 1 I units in Little Santeetlah and rainbow trout in only eight units in Right Fork. Use of 128 units in Right Fork by brook trout was exactly equivalent, and use of 105 units in Little Santeetlah by rainbow trout was nearly equivalent, to use presented in Figure 3 (Table 5) In Lost Cove Creek, all three species were present, although brook trout were found in only 16 units (I 3 with no LWD and one with one piece of LWD). In all comparisons, distributions of individual trout species among units 
TABle 6.-Number of pools and riffles with different amounts $(0, I, 2,3$, or $\geq 4$ pieces) of large woody debris (LWD) occupied by brook trout in Right Fork and rainbow trout in Little Santeetlah Creek. Distributions among units with LWD in pools and riffles were not significantly different for brook trout in Right Fork (chi-square, $P>0.05$ ) hut were significantly different for rainbow trout in Little Santeetlah (chi-square, $P<0.05$ ). Distribution of rainbow trout among pools in Little Santeetlah Creek does not differ front the corresponding distribution of aggregated trout species and habitat types displayed in Figure 3 (chi-square, $P>0.05)$.

\begin{tabular}{lcccc}
\hline \multirow{2}{*}{$\begin{array}{c}\text { Pieces } \\
\text { of LWD }\end{array}$} & \multicolumn{2}{c}{$\begin{array}{c}\text { Right Fork, } \\
\text { brook }\end{array}$} & trout & \multicolumn{2}{c}{$\begin{array}{c}\text { Litle Santeetlah } \\
\text { Creek, rainbow trout }\end{array}$} \\
\cline { 2 - 5 } & Pools & Riffles & Pools & Riffles \\
\hline None & 51 & 13 & 49 & 10 \\
One & 12 & 7 & 16 & 4 \\
Two & I0 & 3 & 8 & 2 \\
Three & 8 & 4 & 1 & 6 \\
Four or more & II & 2 & 7 & 2 \\
\hline
\end{tabular}

with different amounts of LWD were not significantly different from the aggregated distributions displayed in Figure 3 (Table 5 ; chi-square, $P>$ $0.5)$.

Trout preferentially used pools over riffles in all three streams; utilization indexes (Bisson et al. 1982 ) of trout density were slightly positive (0. 11 to 0.22$)$ for pools and moderately negative $(-0.37$ to -0.58) for riffles in all three streams. Only two riffles in Lost Cove Creek had LWD, so separate analyses for riffle and pool habitats were not possible for this stream. Distributions of brook trout in Right Fork and rainbow trout in Little Santeetlah Creek among riffles and pools with different amounts of LWD were generally not significantly different from each other or the overall distributions in Figure 3 (Table 6; chi-square, $P>0.05$ ). The exception was distribution of rainbow trout among riffles in Little Santeetlah, where trout were underrepresented in riffles with no LWD and overrepresented in riffles with three pieces of LWD (Table 6).

Trout densities (number $/ \mathrm{m}^{2}$ ) in habitat units were significantly different among the three streams (Kruskal-Wallis, $P<0.001$ ), with density in Right Fork $\left(0.35 / \mathrm{m}^{2}\right)$ significantly different from that in Little Santeetlah Creek $\left(0.13 / \mathrm{m}^{2}\right)$ and Lost Cove Creek $\left(0.16 / \mathrm{m}^{2}\right)$ (nonparametric pairwise test, $P<0.05)$. Within streams, density differences among units with different amounts of LWD were not significant (Kruskal-Wallis, $P>$ 0.05), although sample sizes in Lost Cove Creek were too small to make a true comparison (Figure 3). Biomasses were signilicantly different among streams (Kruskal-Wallis, $P<0.05$ ) $-4.3 \mathrm{~g} / \mathrm{m}^{2}$ in Right Fork, I. $3 \mathrm{~g} / \mathrm{m}^{2}$ in Little Santeetlah Creek, and $3.5 \mathrm{~g} / \mathrm{m}^{2}$ in Lost Cove Creek-but differences were signiticant only between Right Fork and Little Santeetlah Creek (nonparametric pairwise test, $P<0.05$ ). Electrofishing sample sizes were too small to test differences in biomass among units with different amounts of LWD within each stream.

\section{Discussion}

In the two streams in old-growth areas, woody debris was much more common than in the stream in second growth, and the differences were generally greater for larger size classes of LWD. Likewise, four streams in unlogged areas of Great Smoky Mountains National Park had greater total woody debris and the larger size-classes were more important than in four streams in logged areas (Silsbee and Larson 1983). In these unlogged streams, as well as ours, woody debris was more likely to be aggregated into debris dams than to occur as individual pieces of wood, compared with logged streams (Silsbee and Larson 1983). The smallest size-class (class 1) of woody debris is relatively common in all stream systems in the southern Appalachians (authors' personal observation).

Large woody debris with diameters greater than $10 \mathrm{~cm}$ (classes 2-3, 5-7) contributes most to creation of habitat units, especially pools, because this material is large enough to be stable in normal Rows (Bilby 1984; Bisson et al. 1987; Bilby and Ward 1989; Swanston 1991; Naiman et al. 1992). An unusually large number of pieces $\mathrm{IO}-\mathrm{SO} \mathrm{cm}$ in diameter and longer than $5 \mathrm{~m}$ in Right Fork may represent continual input of trees that are vulnerable to windthrow in this high-elevation, relatively exposed watershed. In Lost Cove Creek, almost no LWD in the largest-diameter $(>50 \mathrm{~cm})$ sizeclasses (classes 3 and 6) was found, and none was longer than $5 \mathrm{~m}$ (class 6), rellccting the absence of large trees in the watershed. In contrast, relatively large amounts of wood greater than $\mathrm{SO} \mathrm{cm}$ in diameter were found in Little Santeetlah Creek and Right Fork. Much of this wood was eastern hemlock, which is common in the riparian zone. Although downed American chestnut logs are common in upper parts of the Little Santeetlah watershed, American chestnut accounts for less than $10 \%$ of the wood pieces in the stream and on streambanks (Hedman 1992). Wood in the larger size-classes was probably removed from Lost Cove Creek at the time of logging 80 years ago 
or has since decomposed or been transported out of the system. The pieces of LWD of larger diameter are created only in stands that contain large trees. Even after living trees reach large diameters, some time may pass before natural mortality, windthrow, or bank undercutting cause many of them to drop into the stream system (Harmon et al. 1986; Franklin 1992). In Right Fork and Little Santeetlah Creek, the surrounding old-growth forest has been a continuous source of large diameter LWD for the stream. Larger, habitat-forming pieces will not be recruited into Lost Cove Creek until the surrounding forest matures and large trees, characteristic of old-growth forest, become more common.

Greater woody complexity is expected in oldgrowth than in second-growth streams (Franklin et al. 198 1; Harmon et al. 1986). If LWD plays a role in formation of habitat units, we would expect more pools and riffles in streams with more LWD, and Right Fork and Little Santeetlah Creek contained more pools and riffles per kilometer of stream than did Lost Cove Creek (Tables 3, 4). Even though widths of the three streams were similar, average area of pools and riffles was noticeably smaller in Right Fork and Little Santeetlah Creek than in Lost Cove Creek (Tables 3, 4). In stream segments of approximately the same width and length, Little Santeetlah Creek had more but smaller units than Lost Cove Creek, and some units occurred side by side in Little Santeetlah Creek instead of in the distinctly linear configuration of Lost Cove Creek (Flebbe and Dolloff 1993).

Gradient and stream width are two physical factors that may affect retention of LWD in streams. As both gradient and width increase, the potential for loss of LWD increases (Harmon et al. 1986; Bisson et al. 1987; Swanston 1991). Average stream widths for the three streams were similar, varying by only about $1 \mathrm{~m}$ (Table I). However, gradient in Little Santeetlah Creek was about twice as great as in the other two streams (Table 1) and may account for some of the difference in LWD loading between the two streams in old-growth watersheds (Table 4). The Low amount of LWD in Lost Cove Creek could not result from presentday losses associated with gradient, because this stream had the lowest gradient of the three streams, nor could the losses be associated with width, which was only slightly greater than that of Little Santeetlah Creek. In the selected reaches, both width and gradient were controlled to be as similar as possible, and the relationships of LWD and hab- itat structure among streams were similar to those for the complete streams (Tables 3, 4).

Response of trout to increased woody complexity cannot be determined simply by comparing trout density and biomass in the three streams. Density and biomass vary in response to multiple factors, including habitat quality, primary and secondary productivity, harvest, predation and competition, and water quality, which cannot be controlled in a field comparison of different basins. Furthermore, different species of trout in these streams will contribute to differences in biomass among streams. Differences in density and biomass among the three streams or among units with different amounts of LWD within streams generally could not be detected, because these factors interact unpredictably. The sole exception was Right Fork, where density and biomass were significantly higher than in the other two streams.

A more direct approach to the question of trout response was to determine whether trout were using units with more LWD instead of those with less LWD. In all three streams, trout were found in many units that had little or no LWD where other structural components might have been adequate; alternatively, these situations might have represented use of less desirable but most abundant habitat. Many units in Lost Cove Creek and in Little Santeetlah Creek had no LWD, and 91 and $76 \%$, respectively, of all units that did not have trout also lacked LWD. In the remote Right Fork, where LWD was most abundant, only $43 \%$ of units without trout also lacked LWD; here, for various reasons including very low angling pressure, LWD might not have been critical for occupancy of particular units. Use of units with various amounts of LWD by the three species were similar (Table 5), and although overall use of riffles and pools differed, trout used riffles and pools with various amounts of LWD in similar proportions (Table 6). In all streams, units with the most LWD (more than four or five pieces) were always occupied by trout.

More than half of all units in all three systems did not have LWD, and other structural features were responsible for formation of distinct units. For example, $67 \%$ of units in Lost Cove Creek, 49\% in Little Santeetlah Creek, and 19\% in Right Fork had boulders as either a dominant or codominant substrate. However, boulders were not an effective surrogate for LWD in Lost Cove Creek. where boulders were the most common substrate element and LWD was in least supply. In Little Santeetlah Creek, boulder substrate may have been 
detrimental to trout, possibly because the large number of anglers here may target boulder pools. Only in Right Fork, where LWD was in greatest supply, did boulder substrate increase occupancy of units that lacked LWD; here, lack of anglers and the large amount of bedrock substrate (42\% of units) might have made boulders an effective surrogate.

To demonstrate more conclusively the relationship between LWD, habitat, and trout, manipulative studies, in which LWD additions or removals are conducted under controlled circumstances, are required. In these studies, unlike ours, trout behavior and production responses can be compared. Observational studies like ours are nevertheless useful for characterizing relationships in wilderness streams not available for manipulation. We found a range of responses to LWD in these three systems.

Right Fork, the high-elevation brook trout stream in an old-growth watershed with low angling pressure, had the highest amounts of LWD and highest trout density and biomass. Trout were distributed among habitat units with different amounts of LWD roughly in proportion to availability (Figure 3), except that units with more than five pieces of LWD were overoccupied (100\%). In units that lacked LWD, boulders seemed to be an effective surrogate.

The other stream in an old-growth watershed, Little Santeetlah Creek, dominated by rainbow trout, had the highest fishing pressure of the three streams. Here, trout density and biomass were lowest of the three streams, and trout underoccupied units with fewer than two pieces of LWD and overoccupied units with more than three pieces of LWD (Figure 3). In this stream, trout especially underoccupied habitat units that lacked LWD but had boulder substrate. If anglers target pools with boulders and avoid those with LWD, these distribution patterns are consistent.

Finally, Lost Cove Creek in a second-growth watershed had low trout density, but biomass was moderate because of some relatively large brown trout in this stream. Here, LWD amounts were so low that it was difficult to detect a pattern of occupancy by trout; only nine sampled units had any LWD, and only one had more than one piece. Under moderate fishing pressure at the time, trout occupied units with boulders and no LWD at about the same rate as units that lacked both LWD and boulders.

Characteristics of forested landscapes and streams that arc preserved in old-growth wilder- ness can be used to guide managers who will attempt to recreate similar conditions elsewhere. As agencies move to ecosystem management, these guidelines will become important to fisheries biologists in those agencies. Based on these results, there is no justification in removing reasonable amounts of LWD (greater than $\mathrm{IO} \mathrm{cm}$ in diameter and $1 \mathrm{~m}$ long) from trout streams to improve habitat, as specified by some forestry best management practices. These results can be, and are, used to define desired future conditions for southern Appalachian Mountain trout streams. In particular, adding larger pieces of LWD will subdivide streams into more pools and riffles and may increase the number of habitat units occupied by trout. In streams under angling pressure, adding LWD may be more effective than adding boulders to create additional habitat that is not targeted by anglers.

In contrasting these three streams, we found that streams draining old-growth forest had more LWD, and more and smaller pools and riffles than did the stream in a typical second-growth southern Appalachian watershed. Naturally occurring LWD is an important component of trout habitat in southern Appalachian Mountain streams. Large woody debris provides more than cover and substrate for fish and macroinvertebrates (Dolloft 1986; Harmon et al. 1986); it also plays a role in creating and maintaining habitat features such as pools and riffles (Bisson et al. 1987; Swanston 1991). Brook trout, rainbow trout, and brown trout used many of the units with little or no LWD that are very common in all three systems, but trout always used units that had the most LWD. In the absence of high fishing pressure, streams with large amounts of LWD appear to support higher trout density and biomass than streams with little or no LWD.

\section{Acknowledgments}

The authors thank S. Moore and his staff of the Great Smoky Mountains National Park for assistance in Right Fork and M. Seehorn, L. Neuhs, and members of Trout Unlimited for their assistance in Lost Cove Creek. We also thank Henry Wilson and the District Rangers and personnel of the U.S. Forest Service Cheoah and Grandfather Ranger Districts for permission to work and logistic support in the field. R. Biesterfeldt, R. Bilby, C. Clancy, W. Ensign, M. Hudy, D. Lemly, K. Overton, and S. Zarnoch provided helpful reviews of the manuscript. 


\section{References}

Andrus, C. W., B. A. Long, and H. A. Frochlich. 1988. Woody debris and its contribution to pool formation in a coastal stream SO years after logging. Canadian Journal of Fisheries and Aquatic Sciences 45:20802086.

Bilhy, R. E. 1984. Removal of woody debris may affect stream channel stability. Journal of Forestry X2: 609-613.

Bilhy, R. E., and G. E. Likens. 1980. Importance of organic debris dams in the structure and function of stream ecosystems. Ecology 6 1: 1 107-I 113.

Bilby, R. E., and J. W. Ward. 1989. Changes in characteristics and function of woody debris with increasing size of streams in western Washington. Transactions of the American Fisheries Society 1 IX: 36X-378.

Bisson, P. A., and eight coauthors. 1987. Large woody debris in forested streams in the Pacific Northwest: past, present, and future. Pages 143-190 in E. 0 . Salo and T. W. Cundy, editors. Streamsidc management: forestry and fishery interactions. University of Washington, Seattle.

Bisson, P. A., J. L. Nielsen, R. A. Palmason, and L. E. Grove. 1982. A system of naming habitat types in small streams, with examples of habitat utilization by salmonids during low streamflow, Pages 62-73 in N. B. Armentrout, editor. Acquisition and utilization of aquatic hahitat inventory information. American Fisheries Society, Western Division, Bethesda, Maryland.

Bryant, M. D. 1980. Evolution of large, organic debris after timber harvest: Mayhcso Creek, 1949 to 1978. U.S. Forest Service General Technical Report PNW101.

Dolloff, C. A. 1986. Effects of stream cleaning on juvenile coho salmon and Dolly Varden in southeast Alaska. Transactions of the American Fisheries Society 115:743-755.

Dolloff, C. A. 1994. Large woody debris - the common denominator for integrated environmental management of forest streams. Pages 93-108 in J. Cairns, Jr., T, V. Crawford and H. Salwasser, editors. Implemcnting integrated environmental management. Virginia Polytechnic Institute and State University, Blacksburg.

Dolloff, C. A., D. G. Hankin, and G. H. Reeves. 1993. Basinwidc estimation of habitat and fish populations in streams. U.S. Forest Service General Technical Report SE-83.

Flebbe, P. A. 1994. A regional view of the margin: salmonid abundance and distribution in the southern Appalachian Mountains of North Carolina and Virginia. Transactions of the American Fisheries Society $123: 657-667$.

Flebbe, P, A., and C. A. Dolloff. 1993. Hahitat structure and woody debris in southern Appalachian wilderness streams. Proceedings of the Annual Confcrencc Southeastern Association of Fish and Wildlife Agencies 45( 1991 ):444 450.

Franklin, J. F. 1992. Scientific basis for new perspec- lives in forests and streams. Pages 25-72 in R. J. Naiman, editor. Watershed management. SpringerVerlag, New York.

Franklin, J. F, and seven coauthors. 1981, Ecological charactcristics of old-growth Douglas-lir forests. U.S. Forest Service General Technical Report PNW- 118.

Grant, G. E., F. J. Swanson, and M. G. Wolman. 1990. Pattern and origin ofstepped-bed morphology in highgradient streams, western Cascades, Oregon. Geological Society of America Bulletin 102:340-352.

Hankin, D. G., and G, I-I. Reeves. 1988. Estimating total fish abundance and total habitat area in small streams based on visual estimation methods. Canadian Journal of Fisheries and Aquatic Sciences 45:X34-844.

Harmon, M. E., and twelve coauthors. 1986. Ecology of coarse woody debris in temperate ecosystems. Advances in Ecological Research 15:133-302.

Hedman, C. W. 1992. Southern Appalachian riparian zones: their vegetative composition and contributions of large woody dehris to streams. Doctoral dissertation. Clemson University, Clemson, South Carolina.

Hicks, B. J., J. D. Hall, P. A. Bisson, and J. R. Sedell. 1991. Responses of salmonids to hahitat changes. American Fisheries Society Special Publication 19: 483-S 18.

Larson, G. L., and S. E. Moore. 1985. Encroachment of exotic rainbow trout into stream populations of native brook trout in the southern Appalachian Mountains. Transactions of the American Fisheries Society 114 : 195-203.

Lorimer, C. G, 1980. Age structure and disturbance history of a southern Appalachian virgin forest. Ecology 6 1: 1 169-1 I X4.

Mcehan, W. R., editor. 1991. Influences of forest and rangeland management on salmonid fishes and their habitats. American Fisheries Society Special Publication 19.

Murphy, M. L., and W. R. Mcehan. 1991. Stream ecosystems. American Fishcries Society Special Publication 19: $17-46$.

Naiman, R. J., and eight coauthors. 1992. Fundamental elements of ecologically healthy watersheds in the Pacific Northwest coastal ecoregion. Pages 127-I XX in R. J. Naiman, editor. Watershed management. Springer-Verlag, New York.

Neter, J., W. Wasserman, and M. H. Kutner. 1990. Applied linear statistical models. Irwin, Homewood, Illinois.

Platts, W. S., W. F. Megahan, and G. W. Minshall. 1983. Methods for evaluating stream, riparian, and biotic conditions. U.S. Forest Service General Technical Report INT- 13X.

Pyle, C. 1985. Vegetation disturhancc history of Great Smoky Mountains National Park: an analysis of archival maps and records, National Park Service, Southeast Region, Research/Resources Management Report SER-77, Atlanta.

Rosgen, D. L. 1994. A classification of natural river-s. Catena 22: 169-199.

SAS Institute. 1985. SAS guides for personal comput- 
ers, version 6 edition. SAS Institute. Cary, North Carolina.

Silsbee, D. G., and G. L. Larson. 1983. A comparison of streams in logged and unlogged areas of Great Smoky Mountains National Park. Hydrobiologia 102:99-111.

Swanston, D. N. 1991. Natural processes. American Fisheries Society Special Publication 19: 139-I 79.
Vitousek, P. M., and W. A. Reiners, 1975. Ecosystem succession and nutrient retention: a hypothesis. BioScience 25:376-381.

Williams, M. 1989. Americans and their forests: a historical geography. Cambridge University Press, Cambridge.

Zippin, C. 1958. The removal method of population estimation. Journal of Wildlife Management 22:82-90. 